Iryna Novikova,

PhD in Economics, Senior Researcher, Taras Shevchenko National University of Kyiv (Kyiv, Ukraine);

Victor Martyniuk,

Doctor of Science (Biology), Professor, Taras Shevchenko National University of Kyiv (Kyiv, Ukraine);

Alexander Bediukh,

PhD, Senior Researcher, Taras Shevchenko National University of Kyiv (Kyiv, Ukraine);

Olena Kharina

PhD in Economics, Researcher, Taras Shevchenko National University of Kyiv (Kyiv, Ukraine)

\title{
ACADEMIC CAPITALISM: DEVELOPMENT TRENDS IN UKRAINE AND EUROPEAN PRACTICE
}

The article outlines the trends in the formation of academic capitalism in Ukraine. There Also have been described the trends of development of business environment in the field of high technology in Ukraine and abroad, particularly in universities, as well as patterns of commercialization of results research activities in the context of strengthening the importance of knowledge. The obtained results will allow forming the principles for the formation of a new methodological paradigm for managing the technology transfer process, taking into account the peculiarities of the development of domestic science, economy, entrepreneurship and the market of high technologies.

Keywords: academic capitalism, innovation, knowledge-intensive business, commercialization, technology transfer center, scientific and technical products, patents, eurointegration.

DOI: 10.21272/mmi.2018.1-02

Introduction. Market relations predominant in the majority of world countries have laid down the rules based on entrepreneurship and competition in all economic sectors without exception. Global challenges and fight for the capital have consumed social institutions as well. Today, education and science have also become the economic agents, since due to critical lack of resources, even the world's leading universities faced the need to look for the ways to survive over the last few decades. Social and economic changes resulted in a situation where modern universities are intended to meet the market demands, rather than social ones. Within the context of the science-based economy concept development, the universities have gained extensive autonomy rights, along with the chance to push on to the next development level as a result of academic entrepreneurship. Subsequently, famous education and research institutions overseas have ended up becoming centers for innovative activities. In light of this, the role of researchers and academ ic research has increased considerably, since the deliverables of scientific research have become the subject of commodity-money relations, while the most commercially appealing intellectual property items have turned into valuable products. Understanding the importance of the innovation processes evolution in Ukraine generates the need for identification of the trends in academic capitalism formation.

Aim of the article is to analyze the process of science-based business environment development in Ukraine and around the globe, particularly in the universities, as well as to define the patterns of scientific research deliverables' commercialization within the context of strengthening the knowledge relevance.

Literature review. The marketlaunch of innovative products has been the focus of research papers by many well-known foreign authors, in particular H. Etkowit [1], D. Mawson [2; 3], B. Clarke [4], E. Rogers [5], T. Hockaday[6; 3], Sh. Harrison [3], G. Chesbro [7], and others. In his popular monograph "The Triple Helix: University - Industry - Government Innovation In Action", Henry Etzkowitz claim s that universities should play the key role in shaping and implementing new ideas and technologies, since 
they form the very core of country's scientific and economic potential [1]. In turn, Everett M. Rogers in his book "Diffusion of Innovation" points out that implementation of innovations in the companies depends on the adopted individual decisions [5]. Various aspects of innovations and ways to commercialize them have been examined in publications by distinguished domestic scientists G.Androshchuk [8], L. Antoniuk [9], V.Bazylevych [10], V.Geyets [11; 19], N.Grazhevska [12], A.Danylenko [13; 19], O. Zhylinska [14], V.llyina [10], Yu.Kapitsy [18-19], as well as young researchers V.Virchenko [15], A. Vitrenko [16], A.Vikulova [17] etc. The key mechanisms and m ethods of innovation commercialization have been investigated by Chih-Hung Shai [20], T. Chekulina [21], O.I. Derengovsky [22] and others.

However, notwithstanding the fact that the issue concerning sale of innovations in the market is not radically new, there are still many uninvestigated aspects of this essential economic field both in science and practice.

The concepts of modern macro and microeconomic theory, as well as innovation management have laid the theoretical and methodological foundation of this research. The studies and developments by domestic and foreign researchers engaged in examining the matters associated with technological advances, innovation development and commercialization of scientific research deliverables, legal documents of Ukraine and the EU, data books and Internet resources have been used in the paper. Comparative approach, the methods of analysis, synthesis and theoretical generalization, as well as economic and statistical methods of actual data analysis have been applied in the course of research. Through the application of comparative approach, the institutional forms of science-to-business technology transfer in the EU countries and Ukraine have been identified. The regulatory framework in the field of academic knowledge commercialization has been analyzed using the methods of analysis and synthesis. The analog approach has been applied in order to identify the differences between the global and domestic trends in commercialization of technologies, particularly, in terms of intensity of invention patenting and the benefit from the sale of high-tech products. Using the generalization method, the issues arising in the course of development of Ukraine's science-based business environment have been outlined. The theoretical conclusions have been drawn based on processed statistical and analytical data retrieved from the official foreign and domestic sources, as well as analysis of own factual materials and findings.

Against the backdrop of the evolution of environment of innovation in the world's leading countries, recent global trends consist in transition from the "linear model" of innovation cycle management to "cooperative model" based on so-called "entrepreneurial university" [19, p. 163]. It is a cutting-edge education and research institution that effectively brings together education and science with commercial subtext. The acquired knowledge is then immediately used in research with a focus on further commercialization of its deliverables. Today, the processes linked to commercialization of scientific and research inventions and developments depend largely on operation efficiency of the modern academical structural departments professionally engaged in science-to-business technology transfer. In view of this, the key factors of scientific research deliverables' commercialization are the principles and terms of implementation of scientific ideas and developments, as well as the form of their transfer and degree of ultimate profitability.

Currently, the majority of the world's scientific and educational research institutions use 11 most common institutional forms of technology transfer: division, department, innovation division, own business, stake in business, division operating on subcontract terms, regional technology transfer subdivision, Satt program, own incubators, incubators affliated with the universities, and independent incubators [3, p. 25-31]. Virtually, all of them have different legal status, but nonetheless work on the main innovation generator, i.e. the university, which has full authority to enter the market and secure profits.

Given that the commercialization of the scientific research deliverables has not gained any true 
relevance in Ukrainian practice yet, complex and multifunctional models of technology transfer have not been developed in domestic scientific research environment in the years following independence. The most standard model of technology transfer is a division that directly handles the know-how transfer to the business entities, as well as distribution of application-oriented scientific and technological knowledge, and operates on the premises of the university. Its activities are complex, and the model of operation may vary based on the type of university. The most common and traditional type of technology transfer division is the department which is often set up on the premises of the medium-level research universities with several people being em ployed. Typically, such universities are short-staffed, so the specialists working in these structural units are under-qualified. In the majority of cases, this type of departments is invisible, for the most part operates at a loss and is unable to fulfill its direct functional purpose. The advantage of this institutional form of technology transfer is explained by the simplicity of its establishment - based on internal order of the university's administration - and relative inexpensiveness of its operation. In particular, these departments are arranged on the premises of Vadym Hetman Kyiv National Economic University [23], the Odesa National Polytechnic University [24], the Kyiv National University of Technology and Design [25], the National Transport University of Ukraine [26], and some other higher education institutions, the official websites of which make no mention of them, as in case of the Lutsk National Technical University [27], or if there is some type of information about them, their activities are not listed, as in Dneprodzerzhinsk State Technical University [28].

In contrast, the universities overseas have relevant departments i.e. integrated divisions which are larger in size (the number of em ployees in some of the biggestuniversities such as Harvard or Stanford reaches up to 60-70 people) and provides a wider range of services within the framework of academic research market promotion. In broad terms, it is a much better organized structure with an increased relevance and accountability, since their heads often report directly to the Rector or Vice Rector for Research who is in charge of research activities, and, in some cases, concurrently holds both positions and/or fulfills either duties. This contributes to sufficient integration of this division into university's research ecosystem and offs greater freedom of maneuver. However, the major drawback of these activities includes lack of complete independence, which in some cases slows down the process of technology transfer. In Ukraine universities and research institutes often have the problem of excessive and contradictory dependence on the process of im plementation of promising innovative projects. This is the main reason for the fact that the most interesting projects usually those that have support of international organizations can be implemented only outside the jurisdiction of universities in Ukraine, and therefore cannot provide proper economic and investment returns to the national alma mater.

Innovation divisions that generate innovative proposals associated with other programs are sometimes established on the premises of foreign universities. Such offices operate separately from purely research areas of work and community groups, while at the same time enabling the university and external organizations to conduct their activities in a single-window mode. Commonly, they have their own financial departments, implement professional technology transfer, supervise student venture companies, train employees and offer wide-ranging business support. Their major advantage lies in provision of a full package of innovative services. For instance, Cambridge Enterprise, the subsidiary owned by the University of Cambridge is engaged in research commercialization. It works with university members throughout all stages of commercialization process ranging from legal support of received applications for research projectfunding and advising to facilitation of patent and license acquisition, as well as incorporation of new companies based on research developments of the university.

However, today's latest model for commercialization of academic technologies is the business fully owned by the university with the key focus on com prehensive technology transfer management, advisory activities, and provision of innovation management services to the customers worldwide. The shining 
exam ple of this is Oxford University Innovation, a subsidiary owned by the University of Oxford [30]. This versatility in the style of activities implies a certain level of autonomy from the parent university and the ability to follow a more liberal commercial strategy, unlike other institutional forms in technology transfer field which are mostly bound by business relations with "their" universities. In such a case, the advantages of making the best use of the university's brand, namely the ability to attract a bigger number of customers, partners and investors, remain.

In this context, the obvious pattern can be observed: the more attention the university devotes to the infrastructure development in the field of technology creation and transfer, the more economic return it can expectas a result of com mercialization of research and development deliverables produced under its brand name.

Thus, the number of the best innovative profile developments given in the European Enterprises Network (EEN) database offers illuminating insights into the best performance of the countries, where a complex of linked servicing facilities providing the foundation for the innovation system operation in the universities is sufficiently developed and meets the demands of today's market (Table 1). In Ukrainian state education, science and research institutions, the innovation and investment management is at conception stage, and currently even those universities that have already recognized the need for its implementation have yet to fully realize the importance and relevance of introducing adequate mechanisms and processes.

Table 1 - Profiles of innovative developments given in the EEN database* [31]

\begin{tabular}{|l|c|c|c|c|c|c|}
\hline & Great Britain & Poland & Germany & France & Romania & Ukraine \\
\hline Total last year & 482 & 539 & 361 & 308 & 348 & 118 \\
\hline Business offer last year & 390 & 476 & 188 & 219 & 329 & 87 \\
\hline Technology offer last year & 92 & 63 & 173 & 89 & 19 & 31 \\
\hline
\end{tabular}

*as of March 25, 2018

In the process of commercializing research and development deliverables, the key objective of the universities and relevantdivisions engaged in science-to-business technology transfer is the maximum value capture, and so the modern higher education institutions are interested in implementing the projects involving incorporation of the new companies based on in-house developments, ideas and know-hows. Therefore, hundreds and thousands of small but profit-generating innovation companies are set up every year on the premises of the world's top universities or jointly with them. For instance, at the University of California, USA which is the economic powerhouse of the region, five new inventions, the commercialization of which starts from the lab, emerge daily [32]. We can clearly see the pattern here: the way the science-production system is arranged does not depend on the forms of ownership, since the profits can be generated both through implementation of licenses to use inventions patented by the university and by holding the share in the company based on the principle of venture capital investment. However, the majority of research and developmentactivities in Ukraine are commissioned by the state agencies, which are in charge of that and have relevant powers associated with funding allocation. Meanwhile, hundreds of successfully implemented research activities have not been commercialized. The following patternmust be emphasized here: the one who gains the most advantageous market position is not the one who develops some of the best solutions and products, but the one who is able to ensure maximum synergetic effect resulting from the synthesis of local technologies when creating the market product, as well as the cooperation between the customer, the seller and the external environment.

In Ukraine, the entrepreneurial passiveness in the science-based field is one of the key roadblocks 
to development of an efficient market for academic knowledge and technologies. This situation is explained by the fact that commercialization of scientific breakthroughs is somewhat new in our country, since during the Sovietera all research developments were used for the sole benefit of the state, and so there was no need to search for any other potential customers for this product. On the flip side, the officials of different levels do notfully realize the actual social benefits of investing into science projects, since our society has a somewhat distorted idea of their socio-economic impact.

For this reason, the need to improve the state innovation policy is being formed in Ukraine. In particular, this can be achieved through development of mechanisms for meaningful cooperation between the universities, the business and the state which have been successfully operating as a "triple helix model of innovation" in the Western world for quite some time now [1;19]. The implementation of principles for management of scientific research deliverables will encourage further emergence of hightech innovations, since it will accommodate the interests and accumulate resources of all parties involved.

However, in a civilized world, the process of intellectual property commercialization is regulated through other means as well, in particular by creating the conditions, under which innovation activities become an actual key factor in development of the national economy. This complex of linked actions requires creation of innovation infrastructure, development of mechanisms to encourage innovation activities, identification of priority directions for building the economic strength of a developed state, along with development and adoption of relevant laws and regulations.

Currently, the main lawallowing to regulate transactions associated with technology transfer to other recipients is the Law of Ukraine "On State Regulation of Activities in the Field of Technology Transfer" passed in 2006 [33] and outining legal, economic, organizational and financial principles of activities in this field. Operation of this law became a turning point in the context of scientific and research developments commercialization process, since as of the time of law passage, just like today, the country had practically no competent experts who would be able to get the transfer of the new technologies or innovations for commercial use up and running. In addition, this norm-setting document has plenty of drawbacks and contradictions, considerably complicating the commercialization of sciencebased technologies and innovations.

The crucial aspect in encouragement of technology transfer as a key factor in innovation process intensification in the national economy is efficient stimulating tools of operation of all parties involved in technology transfer, and mainly the employees directly engaged in the market promotion of technologies. In fact, the idea of receiving profits from the use of technologies in the course of business activities is aimed not only at expanding the scale and speeding up the pace of industry modernization on an innovative basis, butalso creating additional remunerative incentives for the scientists who are the key players directly generating valuable research deliverables which are the very evolutionary foundation of the mankind. Thus, another pattern proves that the commercial success of innovation depends both on exogenous (technological, social, psychological and economic) and endogenous (creativity of the individual) factors, namely $5 \%$ of the economic factor, $5 \%$ of the psychological factor, $10 \%$ of the social factor, $25 \%$ of technological development level, and $55 \%$ of the quality of creative thinking [22, p.16]. The basis of the creative (author) component in the science-based innovation business is evidenced by yet another pattern. Nearly until the mid-60's of the 20th century, the success of the final innovative product depended greatty on the contribution of the author who put major personal effort into its market promotion, thus acting as an inventor and entrepreneur at the same time. Almost $40 \%$ of all commercially-viable inventions back then became profitable family businesses owned by those who created them.

Later on, the privately-owned innovative businesses have been squeezed out by the corporate ones. Because of this, large innovation-oriented transnational corporations, such as Boeing, Intel, Google, and 
Microsoft guided by the strategy of accumulation of the world's best intellectual assets have now become the owners of intellectual property and the source of innovations [34]. However, it is evident that the scientists keep playing a leading role in organization of successful science-intensive business, and therefore should receive adequate royalties.

From this perspective, Part 5, Art. 22 of the Law of Ukraine "On State Regulation of Activities in the Field of Technology Transfer" em phasizes the need to set minimum rates of royalties for creators of technologies and those who carry out their transfer. In addition, the Decree "On Approval of Minimum Rates of Royalties for Technology Creators and Individuals Carrying Out Their Transfer" passed by the Cabinet of Ministers of Ukraine in 2008 explicitly outlines them; however, on a practical level these rules are hardly applied [35].

The Law "On Higher Education in Ukraine", 2016 has had a direct impact on evolution of Ukraine's scientific and research developments market as well. According to this law, domestic higher education institutions were granted new rights and opportunities [36]. However, it has also had substantial controversies concerning the investment and commercialization processes in the field of science. In particular these are the contradictions which touch the autonomy and opportunities of the universities to create new models proceedings research activities (in accordance with Article 30 of this Law). Taras Shevchenko National University of Kyiv, according to Article 70 of this Law, has the right to carry out independently financial and economic activities, including receive profit. In particular, it has the right to form innovative structures of different types (scientific and technological parks, business incubators, small companies etc.) on their premises by bringing together interests of high-tech companies, science, education, business and the state for the purpose of implementing other innovative projects. It also has the right to open current and deposit bank accounts within the framework of financial freedom etc. However, outdated algorithms and artificial barriers in the budgeting process continue to hinder essential the implementation of innovative processes in public universities.

Thus, on the one hand, our country technically continues to declare the high-priority social nature of the activities carried out by domestic higher education institutions, the key tasks of which are to promote the increase and spread of scientific knowledge, as well as to carry outcultural and educational activities based on the principles of patriotism, morality, responsibility etc. [36] Yet it is developing not yet quite visible institutional instruments to implement the proven foreign formula of academic capitalism, which implies combination of commercial interests of the public authorities, market/businesses and the academic comm unity. In modern sense there are several theories regarding the definition of the term "academic capitalism". However the main, according to the authors, thing it is that this is the process of transforming universities or research institutes from non-profit socially-oriented organizations into commercial enterprises, which leads to the need for direct market activities patents, licenses, etc.) for profits (, as well as increased competition for the opportunity to attract investment funds and profitable commercial contracts with other academic enterprises. The role of researchers also changes substantially. They become scientific managers.

In Europe, the activities linked to knowledge transfer and research and technology commercialization are governed by specific legislative instruments, in particular the European Commission Recommendations on the Management of Intellectual Property in Knowedge Transfer Activities, and the Code of Practice for universities and other public research organizations [37]. Over the recent years, open innovation models of the form of partnership between the universities, the private industry and the state adm inistrations of different level have become increasingly widespread within the framework of the Europe 2020 strategy. This speeds up the spread of knowledge, stimulates innovation activities, and enables to create an environment that has a favorable investment climate.

In addition, innovation activities are affected by global macroeconomic factors, such as geopolitical challenges, macroeconomic policy of the country, socio-economic stability, efficiency of reforms in 
business activities, income level and standard of living of the population, including innovators etc. Thus, economic and political turmoil results in a sharp deterioration of the financial and economic climate of the country, which, in turn, triggers macroeconomic equilibrium disturbances, termination of close and longterm economic relations, slump of production, com plication of monetary-and-credit relations between marketplayers, inflation, bankruptcies of the companies and banking institutions, rising unemployment rate and subsequently a significant impoverishment of the citizens.

In this context, the well-known domestic professors Reshetnikova I.L. and Sagaydack M.P. prove that the "shock therapy" that was introduced in the Ukrainian economy following the Revolution of Dignity in 2014, delayed reforms and overall political instability resulted in harsh austerity measures, for which reason costly innovation projects became "deferred expenses" [38]. Due to this, the number of industrial enterprises engaged in innovation activities has decreased dramatically. Thus, only 824 or $17.3 \%$ of industrial enterprises with 50 or more employees were formally engaged in innovative activities in 2015 (see Table 2), as compared to 1,609 in 2014. According to official statistical data, they have spent UAH 13.8 billion or USD 510.3 million ( $0.7 \%$ of GDP) on innovations, in particular UAH 11.1 billion on the purchase of machinery, hardware and software, UAH 2.0 billion on internal and external scientific and research developments, and UAH 0.1 billion on the purchase of the new pieces of technology. As in previous years, own funds of the enterprises amounting to UAH 13.4 billion were the primary source used to cover innovation expenses. The volume of the attracted state budget funding totaled UAH 55.1 million, UAH 58.6 million of foreign investments, and UAH 273.0 million of funds from other sources. That said, they have sold innovative products worth only UAH 23.1 billion, with only UAH 10.8 billion outside Ukraine. [39]. According to the currentexchange rate UAH 27/USD 1, this is about USD 4 billion which is $8.4 \%$ of the total volume of goods and services exported by our country in 2015 . Thus, it is evident that implementation of promising long-term innovative projects needs stable operation of the key institutions of science-based business, as well as macroeconomic equilibrium, clear and stable state policy in this field, firm rights of the intellectual property holders and business entities actually bringing the know-hows into their activities, reasonable cost estimate of the commercially-viable deliverables of the creators etc. This pattern is essential for development of efficient science-based business environment.

Low innovative activities impede competitive growth of Ukraine globally, hinder innovative economy development process, significantly reduce defense potential and slow down the pace of the European vector of development. According to the Global Economy ranking, out of 140 countries Ukraine was ranked 41 th in the export of high-technology products in 2014; in 2015, Ukraine did noteven make it into the list of 65 countries [42], whereas the World Bank figures show that the global volume of high technology export reached over $\$ 2$ trillion in 2014. The maximum innovation and export volumes were operated by China with $\$ 558.6$ billion. Germany was ranked second with $\$ 199.7$ billion, the US was ranked third with $\$ 155.6$ billion, followed by Singapore with $\$ 137.3$ billion, South Korea with $\$ 133.4$ billion, France with $\$ 114.7$ billion, and Japan with $\$ 123.4$ billion. The share of Ukraine is only $\$ 1.9$ billion. [43].

Currently, the world's key technological sectors, where high technologies are traded, are biotechnologies, medicine, computer technologies and telecommunication, aerospace, nuclear field and optoelectronics, while Ukraine is a supplier of basic metals and products ( $\$ 9$ billion), grain crops (about $\$ 8$ billion), machinery and equipment ( $\$ 4$ billion), fats and oils ( $\$ 3$ billion), mineral products, such as ore, slag, ashes (\$3 billion), as well as chemical industry products, including inorganic chemicals, pharmaceuticals products, fertilizers, essential oils etc. ( $\$ 2$ billion) [39].

Whereas the world's leading countries make profit off of the export of high-tech products, Ukraine remains to be mostly a raw material supplier. However, in the context of building our country's security and defense, there is a chance to increase the commercial returns from scientific and technological 
І.Е. Новікова, В.С. Мартинюк, О.Р. Бедюх, О.О. Харіна. Академічний капіталізм: українські тенденції формування та європейська практика

activities. Against the backdrop of Russia's aggression towards Ukraine, creating conditions for increase in production output and facilities of the Ukraine's defense industry complex is a significant factor for launching own production of weapon, military and special equipment [44]. To do so, it is planned to boost innovative development of the domestic defense industry complex, in particular, to take relevant measures on development of efficient means for protection of military facilities, as well as other military developments in the future.

Table 2 - Distribution of the total funding of industrial enterprises' innovative activities according to 2010 and 2015 sources (prepared by the authors using own calculation and official statistical data sources [39-41])

\begin{tabular}{|c|c|c|c|c|c|c|c|c|c|c|c|c|c|}
\hline \multirow[b]{2}{*}{$\begin{array}{l}\text { Funding } \\
\text { sources }\end{array}$} & \multicolumn{5}{|c|}{2010} & \multicolumn{5}{|c|}{2015} & \multirow{2}{*}{ 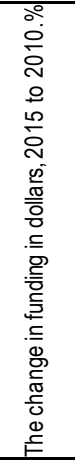 } & \multicolumn{2}{|c|}{$\begin{array}{c}\text { Growth rate, } \\
2015 \text { to } \\
2010, \%\end{array}$} \\
\hline & 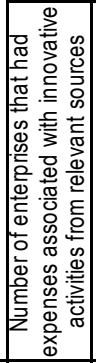 & 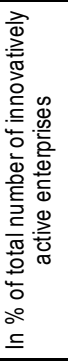 & 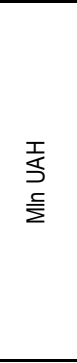 & 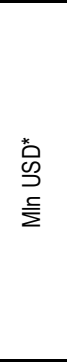 & 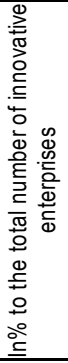 & 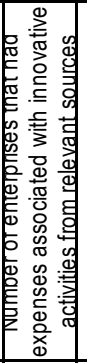 & 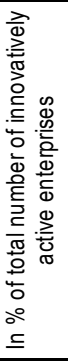 & 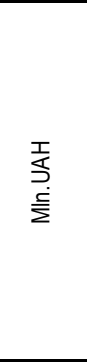 & 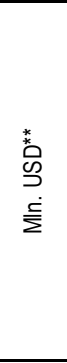 & 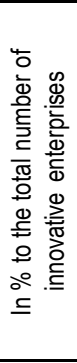 & & 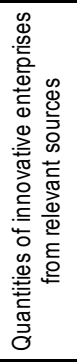 & 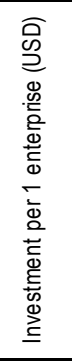 \\
\hline Own budget & 1043 & 71.3 & 4775.2 & 592.4 & 59.4 & 611 & 74.2 & 13427.0 & 496.0 & 851.4 & +43.7 & -41.4 & +143.9 \\
\hline $\begin{array}{l}\text { The state } \\
\text { budget }\end{array}$ & 23 & 1.6 & 87.0 & 10.9 & 1.1 & 11 & 1.3 & 55.1 & 2.0 & 3.5 & -67.9 & -52.2 & -32.3 \\
\hline $\begin{array}{l}\text { Local } \\
\text { budgets }\end{array}$ & 17 & 1.2 & 5.7 & 0.7 & 0.1 & 15 & 1.8 & 38.4 & 1.4 & 2.4 & +242.9 & -11.8 & +300.0 \\
\hline $\begin{array}{l}\text { Extra- } \\
\text { budgetary } \\
\text { funds }\end{array}$ & 2 & 0.1 & 0.9 & 0.1 & 0.0 & 1 & 0.1 & 1.4 & 0.1 & 0.1 & 0 & -50.0 & +100.0 \\
\hline $\begin{array}{l}\text { Domestic } \\
\text { investors }\end{array}$ & 12 & 0.8 & 31.0 & 3.9 & 0.4 & 9 & 1.1 & 74.3 & 2.7 & 4.7 & +20.5 & -25.0 & +60.7 \\
\hline $\begin{array}{l}\text { Overseas } \\
\text { investors }\end{array}$ & 11 & 0.8 & 2411.4 & 301.0 & 30.0 & 6 & 0.7 & 58.6 & 2.2 & 3.7 & -98.8 & -45.5 & -97.7 \\
\hline $\begin{array}{l}\text { Lending } \\
\text { resources }\end{array}$ & 36 & 2.5 & 626.1 & 78.2 & 7.8 & 11 & 1.3 & 113.7 & 4.2 & 7.2 & -90.8 & -69.4 & -69.8 \\
\hline $\begin{array}{l}\text { Other } \\
\text { sources }\end{array}$ & 8 & 0.5 & 108.1 & 13.5 & 1.3 & 9 & 1.1 & 45.1 & 1.7 & 2.9 & -78.5 & +12.5 & -53.1 \\
\hline
\end{tabular}

$*_{\text {in }}$ accordance with exchange rate as of January 1,2010 (UAH 8.01/USD 1);

**in accordance with exchange rate as January 1, 2015 (UAH 15.77 /USD 1);

${ }^{* * *}$ innovative active industrial enterprises with the number of employees 50 and more persons

Another roadblock to promotion of scientific and research developments is the chronic underfunding of "science" in domestic universities and research institutions. The scientists are now faced with the issues of survival. These include preservation of the schools of science and intellectual potential, maintaining high international scientific level of research, nurturing the next generation of scientists, ensuring access to the latest equipmentand information resources that are an essential prerequisite for the effective performance of work and achievement of the research objectives, rather than enhancing the innovation potential and commercializing their inventions. Over the recentyears, funding from the overall 
budgetallocated to the science and innovation has gone down dramatically (see Table 3). In contrast, the findings of our research show that the level of state expenditures on science has increased taking into account the hryvnia equivalent. For instance, the Ministry of Education and Science of Ukraine in 2018 for research and development received more than 2 times funds from the general budget than in 2013. At the same time, in dollar terms, the level of science funding decreased by $60 \%$ on average as a result of rapid depreciation of the national currency in 2014-2018, which is unacceptable for creation of effective institutional, socio-economic, legal and information system for managing commercialization of scientific and research developments in higher education and research institutions.

Table 3 - Actual state of funding allocated to the science from the State Budget of Ukraine (prepared by the authors using own calculations and official statistical data sources [45])

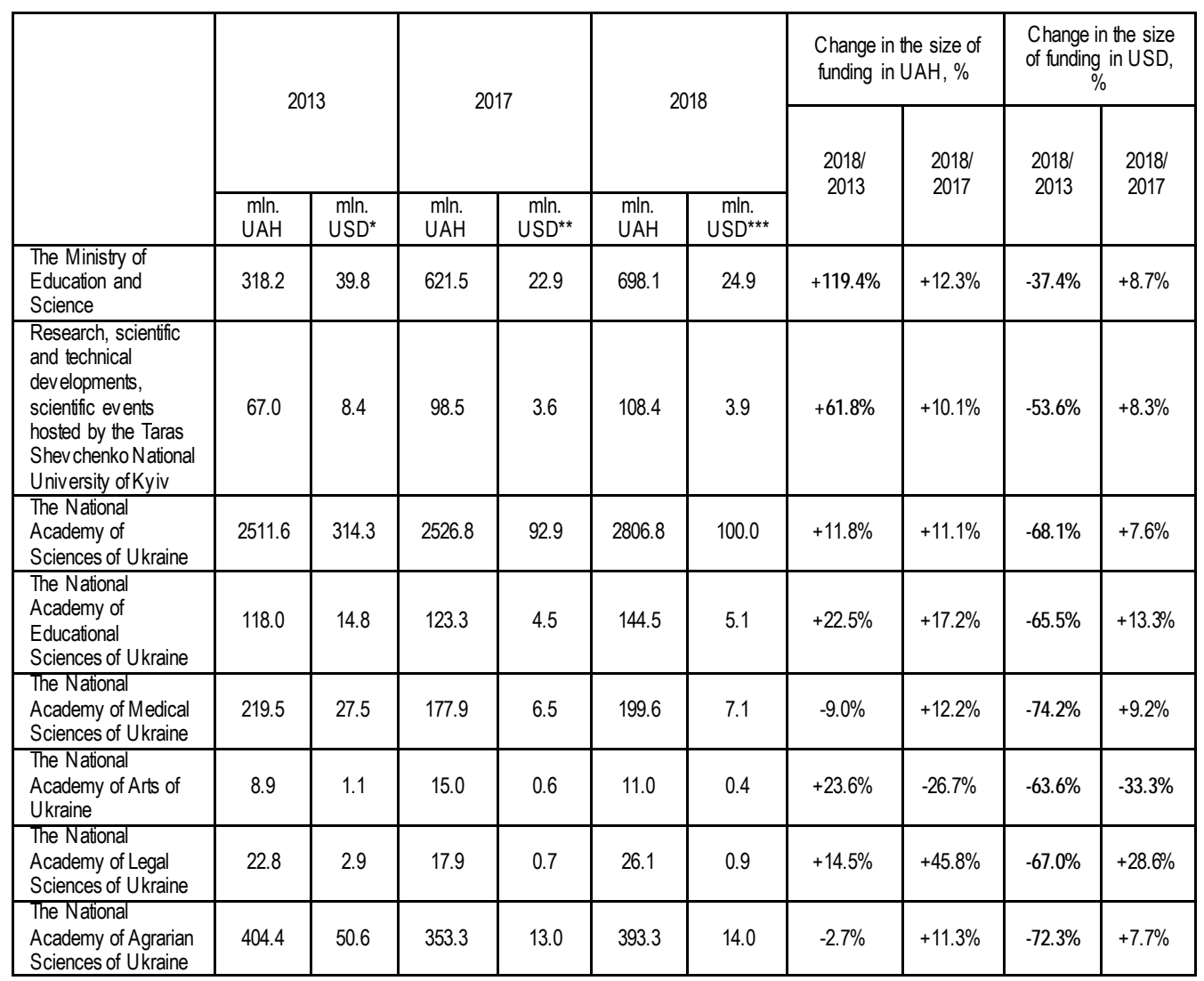

*in accordance with exchange rate as of January 1, 2013 (UAH 7.99 / USD 1);

**in accordance with exchange rate as January 1, 2017 (UAH 27.19 / USD 1);

***in accordance with exchange rate as January 1, 2018 (UAH 28.07 / USD 1

Legislative uncertainty and critical lack of funding intended for research, development and commercialization of the deliverables of innovative activities in Ukraine is the main culprit of passive behavior shown by domestic developers, when it comes to creating commercially attractive R\&D deliverables and intellectual property protection. To overcome this "empty-pocket" situation, 
І.Е. Новікова, В.С. Мартинюк, О.Р. Бедюх, О.О. Харіна. Академічний капіталізм: українські тенденції формування та європейська практика

O.I. Zhylinska suggests developing and implementing purpose-oriented programs in order to boost technology transfer, granting credits on easy terms to encourage scientific and technical cooperation with small and medium-sized enterprises which will stimulate the climate for entrepreneurship, and spreading information aboutcommercially-viable research and development projects among potential investors etc. [14].

In addition, innovation experts note that only $8-10 \%$ of the launched projects manage to achieve commercial success. For example, in the aforementioned University of California, the effectiveness of investment in own patents in 2009 was presented as the Pyramid of Disappointment: out of 400 inventions patented that year, only 50 were implemented in the form of licenses, of which 16 generated some profit, and only one license gave profit exceeding \$1 million. [32]. This pattern is identification of relationship between the quantitative and qualitative side of science-based business. The measure for efficiency of R\&D deliverables commercialization is the number of patents, since they protect inventions and stimulate their emergence. According to 2015 data of the World Intellectual Property Organization, all countries of the world filed 2.9 million (!) patent applications [46], of which only 4,497 (!) were submitted by Ukraine [47]. The biggest number of patent applications was filed by Chinese inventors, namely 1,101,864. The US was ranked 2nd with 589,410 submitted applications (see Table 4). However, Chinese innovators focus largely on the practical application of their inventions in their own country, and therefore submitted only 42,154 patentapplications outside China, whereas the US innovators are more geared towards the outside world, having filed as many as 237,961 patentapplications abroad, which, in turn, makes them the leader.

Table 4 - Impact of research and development funding level on commercialization of intellectual activity deliverables, 2015 (prepared by the authors using own calculation and official statistical data sources [39-40; 46-54],)

\begin{tabular}{|c|c|c|c|c|c|c|c|c|}
\hline \multirow[t]{3}{*}{ Countries } & \multicolumn{4}{|c|}{$\begin{array}{l}\text { Number of submitted patent applications and } \\
\text { obtained patents, } 2015\end{array}$} & \multirow{3}{*}{$\begin{array}{l}\text { Number of } \\
\text { submitted } \\
\text { patents in the } \\
\text { EU } \\
\text { per } 1 \mathrm{mln} \\
\text { residents, as of } \\
\text { early } 2015\end{array}$} & \multirow{3}{*}{$\begin{array}{l}\text { Number of } \\
\text { researchers } \\
\text { including } \\
\text { those } \\
\text { having } \\
\text { scientific } \\
\text { degree, as } \\
\text { of early } \\
2015\end{array}$} & \multicolumn{2}{|c|}{$\begin{array}{l}\text { Total amount of } \\
\text { funds allocated to } \\
\text { scientific and } \\
\text { research field in } \\
2015, \\
\% \text { of GDP }\end{array}$} \\
\hline & \multirow{2}{*}{$\begin{array}{c}\text { WIPO } \\
\text { Patents }\end{array}$} & \multicolumn{2}{|c|}{ EPO } & \multirow{2}{*}{$\begin{array}{c}\text { US } \\
\text { PTO } \\
\text { Patents }\end{array}$} & & & \multirow{2}{*}{ Total } & \multirow{2}{*}{$\begin{array}{l}\text { Of which } \\
\text { state } \\
\text { investment }\end{array}$} \\
\hline & & Applications & Patents & & & & & \\
\hline China & 1101864 & 31504 & 5721 & 9814 & 4.2 & 1524280 & 2.1 & 0.57 \\
\hline USA & 589410 & 65754 & 42692 & 155982 & 115.74 & 1247125 & 2.77 & 2.06 \\
\hline Japan & 318721 & 50597 & 21426 & 54422 & 169.02 & 682935 & 3.47 & 1.78 \\
\hline $\begin{array}{l}\text { South } \\
\text { Korea }\end{array}$ & 213694 & 18215 & 6411 & 20201 & 127.37 & 345463 & 4.15 & 3.75 \\
\hline Germany & 66893 & 31670 & 24820 & 17752 & 256.97 & 357538 & 2.87 & 1.95 \\
\hline Switzerland & - & 8354 & 7088 & 2841 & 398.67 & $35950^{*}$ & 2.96 & 2.63 \\
\hline Sweden & - & 5075 & 3839 & 2862 & 350.41 & 68670 & 3.16 & 1.58 \\
\hline $\begin{array}{l}\text { Great } \\
\text { Britain }\end{array}$ & 22801 & 7095 & 5037 & 7167 & 83.58 & 289330 & 1.7 & 1.27 \\
\hline Singapore & 10814 & 1029 & 391 & 1048 & 68.9 & 42542 & 2.2 & 0.8 \\
\hline $\begin{array}{l}\text { Russian } \\
\text { Federation }\end{array}$ & 45517 & 788 & 230 & 483 & 2.67 & 449180 & 1.66 & 1.19 \\
\hline Poland & 4815 & 842 & 568 & 223 & 16.02 & 96692 & 0.94 & 0.74 \\
\hline Ukraine & 4497 & 137 & 19 & 64 & - & 90249 & 0.62 & 0.21 \\
\hline World & 2888800 & 279000 & 160028 & 325979 & - & 7358900 & - & - \\
\hline
\end{tabular}

*provided data are for the year of 2012 
Patents are the key profitable sale of intellectual property, since what they do is protect the exclusive rights of their holders. For this reason, conditions for commercializing scientific and research developments must first and foremost be created within the regulatory framework based on the principles of patentlaw, namely creative freedom, exclusive rights of the patent holder(s), innovativeness of items protected by the patents, their mandatory recognition by the state; respect for the interests of the patent holder(s) and society, protection of the deliverables of purely creative activities (product or process), moral and material incentives for the authors etc. [55].

Management of intellectual property asset (hereinafter referred to IPA) commercialization process dictates the need for unbiased evaluation of IPA as a new item of market relations. On a practical level, the evaluation of the commercial potential of intellectual property (hereinafter referred to as the $\mathbb{P}$ ) assets is determined by the cost-benefit evaluation method, consisting in contrasting the expenses with expected benefits for those using this $\mathbb{P}$, although other evaluation methods directly linked to IP ownership rights have been stipulated by the law $[56,57]$. However, in order to evaluate innovative products to the maximum extent, it is critical to prepare an intellectual property portfolio, i.e. entire package of copyright protection documents intended to protect scientific and technological developments, including in other countries worldwide. This is a rather costly procedure which domestic higher education institutions are currently unable to afford.

Thus, even though the public officials explicitly declare that one of the country's top priorities is intensive use and fulfillment of scientific and technical potential, the actual state of technology transfer and mechanism for its implementation in scientific, educational and entrepreneurial activities points to the fact that the country has no market for science-based products. So far, the primary funding source for innovation activities of the universities has been poor budgetary funds that can only maintain the heat, but fail to ignite the fire.

Suggestions. Generally, the authors strongly believe that real changes within the context of arranging commercialization of scientific and research developments will take place, once the country starts following recommendations of the European Union [58] and using instruments in order to to unite the scientific and research sector and business entities for stimulating the research and scientific work. In particular this means its financing ata sufficient level for effective innovative development, i.e. notless than $3 \%$ of GDP (according to international standards) [59] or at least $1.7 \%$ of GDP to reach the norms of financial providing the scientific and research work according to Article 48 of the current Law of Ukraine "On Scientific and Technical Activities". To boost innovative activities of the business it is necessary to provide grant credits on easy terms to companies and organizations able to generate innovations and commercialize them; to develop innovative infrastructure in the regions; to implement various programs; to place state orders for making scientific and technical research and developments in the form of contracts; to create scientific and technical areas having special regime of innovation and investment activities; to establish tax credits for investments involved in the field of innovation; to develop and to approve regulations intended to encourage development of research activities; to stimulate cooperation between academic research and business, as well as the work of the experts engaged in the field of innovation and technology transfer.

Thus, inference should be drawn that the key trends in commercialization of research deliverables are developed based on the principles and terms for materialization of scientific ideas and developments, as well as the forms of their transfer and the extent of eventual profitability. In Ukraine, the process of creating science-based business environment is reflected by the following:

- the scale and level of development of scientific and research developments' commercialization process in Ukraine, as well as the competitiveness of domestic products do not cater to the modern needs of the national innovation system's development or relevant indices and trends in developed countries of the world; 
- in the years following independence, no complex and multifunctional models for technology transfer have beennot fully developed in the Ukrainian scientific academic and research environment;

- the major problem when arranging an efficient process of technology commercialization is the lack of skilled personnel to be em ployed in the technology transfer departments, the key task of which is to encourage development of innovation activities in the country, since the management of the centers for technology transfer often has neither theoretical knowledge nor practical experience in managing innovative projects;

- switching to a commercial basis for development of the Ukrainian science becomes more complicated due to a passive mentality of the scientific community, which the Soviet era with its statecontrolled economy took a toll on;

- essentially, the state, governing bodies of the universities, and research institutions do not use any moral or material incentives designed to encourage the scientists to engage in efficient innovative activities;

- the imperfect regulatory framework ignores i.e. does not stipulate the activities of the entities handling technology purchase and sale: centers for technology transfer, technology transfer networks, innovation centers, expert consulting firms etc.

- due to the lack of own funds, domestic research universities and institution are unable to set up own science-based business;

- insufficient amount of own financial resources used for the genesis and expansion of innovation processes is another factor contributing to low innovation activity and industrial enterprises in Ukraine;

- the businesses showing scanty demand for the know-hows, including academic developments and inventions that allow entering the market with the new competitive products;

- too high a percentage of commercial credits also does not facilitate the process of scientific and research developments' commercialization in Ukraine;

- large long-term investment projects impede the planning of economic and political turmoil's which often occur in the country.

Discussion. The development of schools of science and preparation of highly-skilled professionals in various areas of expertise in Ukraine requires creation of a transparent funding and innovation management mechanisms. Nowadays the efficiency of transfer of newly created technologies for commercial use is unfortunately extrem ely low. In some universities such as the Taras Shevchenko National University of Kyiv, the scientific community makes every effort to get the process of knowedge management up and running on its own, while taking into account available resources. However, the question concerning increase in comm ercial impact of the deliverables obtained by researchers of the university as a result of their activities needs to be worked on further, since virtually the global trends are hardly taken into account.

Prospects for further research. The stated conclusions will afford a solid foundation for finding effective strategies to commercialize deliverables of scientific and technological activities in Ukrainian research institutions.

1. Ицковиц Г. Тройная спираль. Университеты - предприятия - государство. Инновации в действии: монография / Пер. с англ. под ред. А.Ф. Уварова. - Томск: 2010. - 237 с.

2. Mawson J. A patient investment idea worth keeping [Електронний ресурс] / J. Mawson // Linkedin. Patient capital. - 2016. - Режим доступу: htps://www.linkedin.com/pulse/patient-investment-idea-worth-keep ing-james-mawson.

3. Коммерциализация технологий на ранней стадии. Исследование глобальных практик: университеты, корпорации, государство [Електронний ресурс] // Отчет... 2015. - 113 с. - Режим доступу https://www.rvc.ru/upload/iblock/9eb/ESR RVC 2015 RU.pdf.

4. Clark B. The Higher Education System. Academic Organization in Cross-National Perspective / B. Clark. Berkeley University of California, 1983. 
5. Роджерс Е. Дифузія інновацій / Е. Роджерс. - К. : Києво-Могилянська академія, 2009. - 591 с.

6. Tom Hockaday to leave Isis Innovation [Електронний ресурс]. - 2016. - Режим доступу : http://www.globaluniversityventuring.com/article.ph p/5097/tom-hockaday-to-leave-isis-innovation.

7. Чесбро Г. Открытые инновации : создание прибыльных технологий / Г. Чесбро; пер. с англ. В.Н. Егорова. - Москва : Поколение, 2007. - 336 с

8. Андрощук Г.О. Інтелектуальна власність у науково-технічній сфері : методи та принципи вартісної оцінки / Г.О. Андрощук, С.А. Давимука. - Київ : Парлам. вид-во, 2014. - 302 с.

9. Дослідницькі університети: світовий досвід та перспективи розвитку в Україні / Павленко А.Ф. та ін. ; за заг. ред. А.Ф. Павленка, Л.Л. Антонюк. - Київ : КНЕУ, 2014. - 349 с.

10. Базилевич В. Інтелектуальна власність: креативи метафізичного пошуку / В. Базилевич, В. Ільїн. - К. : Знання, 2008. -687 c.

11. Гражевська Н.І. Економічні системи епохи глобалізаційних змін: монографія / Н.І. Гражевська. - К., 2008. - 431 с.

12. Даниленко А.И. Будет ли в Украине «Силиконовая долина»? / А.И. Даниленко // Газета "День". - 2012. - № 181. - С. 7.

13. Геєць В.М. Бар'єри на шляху розвитку промисловості на інноваційній основі та можливості їх подолання / В.М. Геєць // Економіка України. - 2015. - № 1. - С. 4-25.

14. Жилінська O.I. Комплементарні ефекти в активізації розвитку науково-технічної діяльності в інформаційному суспільстві [Електронний ресурс] / О.І. Жилінська // Вісник Київського національного університету імені Тараса Шевченка: серія «Економіка». - 2016. - № 9 (186). - С. 54-60. - Режим доступу : https://doi.org/10.17721/1728-2667.2016/186-9/1.

15. Вірченко В. Еволюція підходів до класифікації об'єктів інтелектуальної власності [Електронний ресурс] / В. Вірченко // Вісник Київського національного університету імені Тараса Шевченка: серія «Економіка». - 2013. - № 135. C. 5-7. - Режим доступу : http://dx.doi.org/10.17721/1728-2667.2013/144-3/1.

16. Вітренко А.О. Захист права інтелектуальної власності в сфері послуг / А.О. Вітренко // Інтелектуальна економіка: глобальні тенденції та національні перспективи : матеріали II Міжнар. наук.-практ. інтернет-конф., 26 трав. 2016 р. Житомир : ЖНАЕУ, 2016. - С. 144-152.

17. Вікулова А.О. Аспекти державного регулювання комерціалізації інтелектуальної власності / А.О. Вікулова // Вісник Київського національного університету імені Тараса Шевченка. Серія “Економіка". - 2013. - № 145. - С. 61-63.

18. Трансфер технологій та охорона інтелектуальної власності в наукових установах: монографія / Ю.М. Капіца та ін. ; за ред. Ю.М. Капіци ; НАН України, Центр інтел. вл. та передачі техн. - К., 2015. - 431 с.

19. Інноваційна Україна 2020: національна доповідь за загальною редакцією: В.М. Гейця та ін.; НАН України. - К., 2015. - $336 \mathrm{c}$.

20. Chih-Hung Hsieh Patent value assessment and commercialization strategy / Chih-Hung Hsieh // Technological Forecasting and Social Change. - 2013. - № 80(2): February. - P. 307-319.

21. Чекулина Т. Механизм коммерциализации инноваций как ключевое направление реализации практикоориентированного подхода в обеспечении инновационного развития экономики / Т. Чекулина // Социально-экономические явления и процессы. - Вып.11. - 2011. - С.219-223.

22. Деренговский А.И. Закономерности успешной коммерциализации разработок и система вовлечения творческой молодежи России в малый инновационный бизнес [Електронний ресурс]: автореферат дис. ... кандидата экономических наук : 08.00 .05 / А.И. Деренговский; Орлов. гос. техн. ун-т. - Орел, 2008. - 23 с. - Режим доступу : http://dlib.rsl.ru/viewer/01003167975\#?page=1.

23. Відділ інтелектуальної власності та трансферу технологій [Електронний ресурс] // Київський національний економічний університет імені Вадима Гетьмана. - Режим доступу : http://kneu.edu.ua/ua/science_kneu/csi/ctr_ivl/.

24. Центр трансфера технологій (ЦТТ) [Електронний ресурс] // Одеський національний політехнічний Університет (ОНПу). - Режим доступу: http://cttopu.ua/?q=uk.

25. Мережі трансферу технологій [Електронний ресурс] // Київський національний університет технологій та дизайну. - Режим доступу : http://knutd.com.ua/transfer/trans_ua/.

26. Відділ з питань трансферу технологій, інноваційної діяльності та інтелектуальної власності [Електронний ресурс] // Національний транспортний університет. - Режим доступу : htp://www.ntu.edu.ua/nauka/intelektualna-vlasn ist/.

27. Сайт Луцького національного технічного університету [Електронний ресурc]. - Режим доступу : http://lutskntu.com.ua/uk.

28. Сайт Дніпровськкого державного технічного університету [Електронний ресурс]. - Режим доступу : http://www.dstu.dp.ua/uni/index.html.

29. Sait Cambridge Enterprise [Електронний ресурс]. - Режим доступу : https://www.enterprise.cam.ac.uk/who-we-are/.

30. Sait Oxford University Innovation [Електронний ресурс]. - Режим доступу : htps://www.innovation.ox.ac.uk.

31. Partnering Opportunities [Електронний ресурс] // Enterprise Europe Network. - Режим доступу http://een.ec.europa.eu/tools/services/SearchCenter/Search/ProfileSimpleSearch?shid=32db25cb-726f-43b0-8b5f-7742d0935799.

32. Сайт University of California [Електронний ресурc]. - Режим доступу : htps://www.universityofcalifornia.edu.

33. Закон України “Про державне регулювання діяльності у сфрері трансфреру технологій". - Режим доступу : http://zakon5.rada.gov.ua/laws/show/143-16. 
34. Садков В.Г. Анализ форм коммерциализации рыночно успешных инноваций XX века / В.Г. Садков, А.И. Деренговский // Инновации. - Вып. 10. - 2007. - С. $46-49$.

35. Постанова Кабінету міністрів України "Про затвердження мінімальних ставок винагороди авторам технологій і особам, які здійснюють їх транссрер" [Електронний ресурс]. - Режим доступу : htp://zakon3.rada.gov.ua/laws/show/520-2008$\% \mathrm{DO} \% \mathrm{BF}$.

36. Закон України "Про вищу освіту" [Електронний ресурс]. - Режим доступу http://zakon2.rada.gov.ua/laws/show/1556-18.

37. European Commission. Commission Recommendation on the management of intellectual property in knowledge transfer activities and code of Practice for universites and other public research organisations [Електронний ресурс] / 2008. - Режим доступу : http://ec.europa.eu/invest-in-research/pdf/download_en/ip_recommendation.pdf.

38. Решетнікова І.Л. Вплив економічної кризи на поведінку вітчизняних споживачів і сприйняття інновацій [Електронний ресурс] / І.Л. Решетнікова, М.П. Сагайдак // Маркетинг і менеджмент інновацій. - 2015. - № 4. - С. 191-205 Режим доступу : htpp://mmi.fem.sumdu.edu.ua/sites/defaultfiles/mmi2016_4_191_205.pdf.

39. Сайт Державної служби статистики України [Електронний ресурс]. - Режим доступу : http://www.ukrstatgov.ua.

40. Аналітична довідка. Стан розвитку науки і техніки, результати наукової, науково-технічної, інноваційної діяльності, трансферу технологій за 2015 рік [Електронний ресурс]. - Режим доступу https://mon.gov.ua/storage/app/media/nauka/infor matsiyno-analitychni/2-3-ad-kmu-2015.pdf.

41. Наукова та інноваційна діяльність в Україні. Статистичний збірник. 2016 р. [Електронний ресурс]. - Режим доступу : htp://www.ukrstatgov.ua/druk/publicatkat_u/publnauka_u.htm.

42. High tech exports - country rankings [Електронний ресурс] // The Global Economy. - Режим доступу : http://www.theglobaleconomy.com/rankings/High_tech_exports/.

43. High-technology exports (current US\$) [Електронний ресурс] // The World Bank. - Режим доступу : htp://data.worldbank.org/indicator/TX.VAL.TECH.CD?end=2014\&name_desc=false\&start=1999.

44. Указ Президента України Про рішення Ради національної безпеки і оборони України від 4 березня 2016 року «Про Концепцію розвитку сектору безпеки і оборони України» [Електронний ресурс]. - Режим доступу http://zakon5.rada.gov.ua/laws/show/92/2016.

45. Бюджет освіти та науки 2013-2018. CEDOS [Електронний ресурс]. - Режим доступу https://docs.google.com/spreadsheets/d/12dkloXQS3iXNurSGOo2ybBI_Yhv0yN_GoObXlihjT8Q/edi\#\#gid=1706382291.

46. Global Patent Applications Rose to 2.9 Million in 2015 on Strong Growth From China; Demand Also Increased for Other Intellectual Property Rights [Електронний ресурс] I/ WPO. - Geneva, November 23, 2016. - Режим доступу:http://www.wipo.int/pressroom/en/articles/2016/article_0017.html.

47. WPO IP Facts and Figures 2016 [Електронний ресурc] // WPO. - Geneva, 2016. - Режим доступу : http://www.wipo.intedocs/pubdocs/en/wipo_pub_943_2016.pdf.

48. Доклад ЮНЕСКО по науке: на пути к 2030 году [Електронний ресурс] // UNESCO. - Режим доступу http://unesdoc.unesco.org/images/0023/002354/235407r.pdf.

49. European patent applications [Електронний ресурс] // European Patent Office. - Режим доступу : http://www.epo.org/about-us/annual-reports-statistics/annual-report2015/statistics/patent-applications.html\#tab6.

50. Your key to European statistics [Електронний ресурс] // Eurostat - Режим доступу : $\mathrm{http}: / /$ ec.europa.eu/eurostat tg $\mathrm{m} / \mathrm{table} . \mathrm{do}$ ? tab =table\&init=1\&language $=$ en\&p code=tsc00004\&plugin=1

51. Singapore [Електронний ресурс] // Sea-eu-net partners in science. - Режим доступу : htps://seaeu.netfacts/sea/singapore\#_ftn4.

52. Показники надходження та розгляду заявок і реєстрації охоронних документів за 2016 рік [Електронний ресурс] // Державне підприємство «Український інститут інтелектуальної власності» (УКРПАТЕНТ). - Режим доступу : http://www.uipv.org/ua/2016-year-expert

53. Фінансування наукових досліджень в Україні та світі [Електронний ресурс] // Економічний дискусійний клуб. - Режим доступу : http://edclub.com.ua/analityka/ finansuvannya-naukovyh-doslidzhen-v-ukrayini-ta-sviti.

54. Patent counts by origin and type calendar year 2015 [Електронний ресурс] // U.S. Patent and trademark office. - Режим доступу : htps://www.uspto.gov/web/offices/ ac/ido/oeip/taf/st_co_15.htm.

55. Закон України “Про охорону прав на винаходи і корисні моделі” від 15.12.1993 № 3687-ХІІ [Електронний ресурс] // Сайт Верховної Ради України. - Режим доступу : http://zakon5.rada.gov.ua/laws/show/3687-12/page.

56. Наказ Фонду Державного майна України "Про затвердження Методики оцінки майнових прав інтелектуальної власності" від 25.06.2008 № 740 [Електронний ресурс] // Сайт Верховної Ради України. - Режим доступу : http://zakon5.rada.gov.ua/laws/show/z0726-08.

57. Постанова Кабінету міністрів України Про затвердження Національного стандарту № 4 "Оцінка майнових прав інтелектуальної власності” від 03.10.2007 № 1185 [Електронний ресурс]. - Режим доступу http://zakon5.rada.gov.ua/laws/show/1185-2007-\% D0\%BF.

58. Hargreaves I. The recommendation to introduce text and data mining in the UK las already made in so called the Hargreaves review. [Електронний ресурс] / I. Hargreaves // Digital Opportunity A review of Intellectual Property and Growth. Available at, 2011. - Режим доступу :htp://webarchive.nationalarchives.gov.uk/20140603093549/ http://www.ipo.gov.uklipreview- 
finalreport.pdf.

59. Сайт Євросоюзу: “Європа 2020”. Цілі Європейської Стратегії інтелектуального, стабільного і продуктивного зростання [Електронний ресурс]. - Режим доступу : http://ec.europa.eu/europe2020/europe-2020-in-anutshell/targets/index_en.htm.

1. Ickovic, G. (2010) Troinaia spiral. Universitety - predpriiatiia - hosudarstvo. Innovatsii v deistvii [Triple helix Universities - enterprises - the state. Innovation in action]. Tomsk [in Russian].

2. Mawson, J. (2016) A patient investment idea worth keeping. Linkedin. Patient capital. Retrieved from https://www.linkedin.com/pulse/patient-investment-idea-worth-keeping-james-mawson.

3. Kommertsializatsiia tehnolohii na rannei stadii. Issledovanie hlobalnykh praktik: universitety, korporatsii, hosudarstvo (2015). [Commercialization of technology at an early stage. Research of global practices: universities, corporations, state] Otchet Report. Retrieved from https://www.rvc.ru/upload/iblock/9eb/ESR_RVC_2015_RU.pdf [in Russian].

4. Clark, B. (1983). The Higher Education System. Academic Organization in Cross-National Perspective. Berkeley: University of California.

5. Rodzhers, E. (2009) Difuziia innovatsii [Diffusion of innovation]. Kyiv [in Ukrainian].

6. Tom Hockaday to leave Isis Innovation (2016). Site of Global University Venturing unw.globaluniversityventuring.com Retrieved from http://www.globaluniversityventuring.com/article.php/5097/to m-hockaday-to-leave-isis-innovation.

7. Chesbro, G. (2007) Otkrytye innovatsii: sozdanie pribylnykh tekhnolohii [Open innovation: vreating profitable technologies]. Moscow [in Russian].

8. Androshchuk, H.O., \& Davymuka, S.A. Intelektualna vlasnist u naukovo-tekhnichnii sferi : metody ta pryntsypy vartisno otsinky [Intellectual property in the scientific and technical sphere: methods and principles of valuation]. Kyiv [in Ukrainian]

9. Pavlenko, A.F. and others (2014). Doslidnytski universytety: svitovyi dosvid ta perspektyvy rozvytku v Ukraini [Research Universities: Global Experience and Development Prospects in Ukraine]. Kyiv [in Ukrainian].

10. 10.Bazylevych, V.D., \& Ilin, V. (2008) Intelektualna vlasnist: kreatyvy metafizychnoho poshuku [Intellectual Property: Metaphysical Search Creatures]. Kyiv [in Ukrainian]

11. 11.Hrazhevska, N.I. (2008) Ekonomichni systemy epokhy hlobalizatsiinykh zmin [Economic systems of the globalization changes]. Kyiv [in Ukrainian]

12. Danilenko, A.I. (2012) Budet li v Ukraine "Silikonovaia dolina"? [Will there be a Silicon Valley in Ukraine?] Gazeta "Den" The newspaper "Den", 181, 7, Retrieved from https://day.kyiv.ua/ru/article/ekonomika/budet-li-v-ukraine-silikonovaya-dolina [in Ukrainian].

13. Heyets, V.M. (2015) Baryery na shlyakhu rozvytku promyslovosti na innovatsiyniy osnovi ta mozhlyvosti yikh podolannya [Barriers to the development of industry on an innovative basis and the possibilities of overcoming them]. Ekonomika Ukrainy Ukraine economy. 1, 4-25, Retrieved from http://nbuv.gov.ua/UJRN/EkUk_2015_1_2 [in Ukrainian].

14. Zhylinska, O. (2016) Komplementarni efekty $v$ aktyvizatsiyi rozvytku naukovo-tekhnichnoyi diyal'nosti $v$ informatsiynomu suspil'stvi [Complementary effects in enhancing the development of scientific and technological activities in the information society]. Visnyk Kyyivs'koho natsional'noho universytetu imeni Tarasa Shevchenka: seriya «Ekonomika» - Bulletin of the Taras Shevchenko National University of Kyiv: series "Economics". 9 (186), 6-16. Retrieved from htps://doi.org/10.17721/17282667.2016/186-9/1_[in Ukrainian]

15. Virchenko, V. (2013) Evoliutsiia pidkhodiv do klasyfikatsii obiektiv intelektualnoi vlasnosti [Protection of Intellectual Property Rights in the Services]. Visnyk Kyivskoho natsionalnoho universytetu imeni Tarasa Shevchenka: seriia «Ekonomika» Bulletin of the Taras Shevchenko National University of Kyiv: series "Economics". 135, 5-7. Retrieved from http://dx.doi.org/10.17721/1728-2667.2013/144-3/1 [in Ukrainian]

16. Vitrenko, A.O. (2016). Zakhyst prava intelektualnoi vlasnosti v sferi posluh [Protection of Intellectual Property Rights in the Services]. Intelektualna ekonomika: hlobalni tendentsii ta natsionalni perspektyw: materialy II Mizhnar. nauk.-prakt. internetkonf. - Intellectual economy: global trends and national perspectives: II International materials. science-practice internet conf (pp. 144-152). Zhytomyr [in Ukrainian]

17. Vikulova, A.O. (2013) Aspekty derzhavnoho rehuliuvannia komertsializatsii intelektualnoi vlasnosti [Aspects of state regulation of commercialization of intellectual property]. Visnyk Kyivskoho natsionalnoho universytetu imeni Tarasa Shevchenka seriia "Ekonomika" - Bulletin of the Taras Shevchenko National University of Kyiv: series "Economics", 145, 61-63 [in Ukrainian].

18. Kapitsa, Yu.M. and others (2015). Transfer tekhnolohii ta okhorona intelektualnoi vlasnosti v naukovykh ustanovakh [Technology transfer and intellectual property protection in scientific institutions]. Kyiv: NAN Ukrayiny, Tsentr intelekt. vlasnosti ta peredachi tekhnolohiy [in Ukrainian].

19. Innovatsiina Ukraina 2020: natsionalna dopovid [Innovative Ukraine 2020: National Report] za zahalnoiu redaktsiieiu (2015) Ukraine. Kyiv. Retrieved from htp://ief.org.ua/wpcontentluploads/2015/07/\%D0\% 86\% D0\% BD\%D0\% BD\%D0\%BE\%D0\%B2\%D0\%B0\%D1\%86\%D1\%96\%D0\%B9\% D0\%BD\%D0\% B0- $\%$ D0\% A3\% D0\% BA\% D1\% 80\% D0\% B0\% D1\% 97\% D0\% BD\% D0\% B0-2020++.pdf [in Ukrainian].

20. Chih-Hung Hsieh (2013). Patent value assessment and commercialization strategy, Article in Technological Forecasting and Social Change 80(2): February, 307-319, Retrieved from https://www.researchgate.net/publication/256859637_Patent_value_assessment_and_commercialization_strategy. 
21. Chekulina, T. (2011) Mehanizm kommertsializatsii innovatsii kak klyuchevoe napravlenie realizatsii praktikoorientrovannogo podkhoda $v$ obespecheniiu innovatsionnoho razvitiia ekonomiki [The mechanism of commercialization of innovations as a key direction for implementing a practice-oriented approach in ensuring innovative development of the economy], Sotsialno-ekonomicheskie yavleniya i protsessyi - Socio-economic phenomena and processes, 11, 219-223. Retrieved from http://cyberleninka.ru/article/n/mehanizm-kommertsializatsii-innovatsiy-kak-klyuchevoe-napravlenie-realizatsii-praktikoorientirovannogo-podhoda-v-obespechenii [in Russian].

22. Derenhovskii, A.I. (2008) Zakonomernosti uspeshnoi kommertsializatsii razrabotok i sistema vovlecheniia tvorcheskoi molodezhi Rossii v malyi innovacionnyi biznes [Regularites of successful commercialization of developments and the system of involving creative youth of Russia in small innovative business]. Extended abstract of candidate's thesis. Orel: OrelSU. Retrieved from http://dlib.rsl.ru/viewer/01003167975\#?page=1_[in Russian].

23. Viddil intelektualnoi vlasnosti ta transferu tekhnolohii [Department of Intellectual Property and Technology Transfer] kneu.edu.ua, Retrieved from http://kneu.edu.ua/ua/science_kneu/csi/ctr_ivl/ [in Ukrainian].

24. Tsentr transfera tekhnolohii (TsTT) [Technology Transfer Center]. ctt.opu.ua, Retrieved from http://cttopu.ua/?q=uk [in Ukrainian].

25. Merezhi transferu tekhnolohii [Technology transfer networks]. knutd.com.ua. Retrieved from http://knutd.com.ua/transfer/trans_ua/ [in Ukrainian].

26. Viddil z pytan transferu tekhnolohii, innovatsiinoi diialnosti ta intelektualnoi vlasnosti [Deparment for technology, innovation and intellectual property transfer]. umw.ntu.edu.ua, Retrieved from http://www.ntu.edu.ua/nauka/intelektualna-vlasnist [in Ukrainian].

27. Site Lutskyi natsionalnyi tekhnichnyi universytet [Site National Technical University of Lutsk], lutsk-ntu.com.ua. Retrieved from http://lutsk-ntu.com.ua/uk [in Ukrainian].

28. Site Dniprovskyi derzhavnyi tekhnichnyi universytet [Site of the Dniprovsky State Technical University], dstu.dp.ua Retrieved from http://www.dstu.dp.ua/uni/index.html [in Ukrainian].

29. Site Cambridge Enterprise, enterprise.cam.ac.uk. Retrieved from https:/www.enterprise.cam.ac.uk/who-we-are/.

30. Site Oxford University Innovation, innovation.ox.ac.uk. Retrieved from https://www.innovation.ox.ac.uk.

31. Partnering Opportunities. Enterprise Europe Network, een.ec.europa.eu. Retrieved from http://een.ec.europa.eu/tools/services/SearchCenter/Search/ProfileSimpleSearch?shid=32db25cb-726f-43b0-8b5f-7742d0935799

32. University of California. universityofcalifornia.edu. Retrieved from https://www.universityofcalifornia.edu.

33. Zakon Ukrainy "Pro derzhavne rehuliuvannia diialnosti u sferi transferu tekhnolohii" [Law of Ukraine "On State Regulation of Activities in the Field of Technology Transfer"]. (n.d.). zakon.rada.gov.ua. Retrieved from http://zakon5.rada.gov.ua/laws/show/143-16 [in Ukrainian].

34. Sadkov, V.G. \& Derenhovskii, A.I. (2007) Analiz form kommercializatsii rynochno uspeshnyh innovatsii XX veka. [Analysis of the forms of commercialization of market-oriented innovations of the XX century]. Innovatsii -Innovations, 10, 46-49. Retrieved from cyberleninka.ru/.../analiz-form-kommertsializatsii-rynochno-uspeshnyh-innovatsiy-xx-v... [in Russian].

35. Postanova Kabinetu ministriv Ukrainy "Pro zatverdzhennia minimalnykh stavok vynahorody avtoram tekhnolohii osobam, yaki zdiisniuiut yikh transfer" [Resolution of the Cabinet of Ministers of Ukraine "On Approval of Minimum Rates of Fees to Technology Authors and Persons Carrying Out their Transfer"] (n.d.). zakon.rada.gov.ua. Retrieved from http://zakon3.rada.gov.ua/laws/show/520-2008-\% D0\% BF [in Ukrainian].

36. Zakon Ukrainy "Pro vyshchu osvitu" [Law of Ukraine "On Higher Education"] (n.d.). zakon.rada.gov.ua. Retrieved from http://zakon2.rada.gov.ua/laws/show/1556-18 [in Ukrainian].

37. European Commission. Commission Recommendation on the management of intellectual property in knowledge transfer activities and code of Practice for universities and other public research organisations (2008). Retrieved from http://ec.europa.eu/invest-in-research/pdf/download_en/ip_recommendation.pdf.

38. Reshetnikova, I.L., \& Sahaidak, M.P. (2015) Vplyv ekonomichnoi kryzy na povedinku vitchyznianykh spozhyvachiv spryiniattia innovatsii [Influence of the economic crisis on the behavior of domestic consumers and the perception of innovations] Marketynh i menedzhment innovatsii - Marketing and Management of Innovation, 4, 191-205. Retrieved from http://mmi.fem. sumdu.edu.ua/sites/defaultfiles/mmi2016_4_191_205.pdf [in Ukrainian].

39. Sait Derzhavnoi sluzhbu statystyku Ukrainy [The site of the State Statistics Service of Ukraine], unw.ukrstat.gov.ua. Retrieved from http://www.ukrstatgov.ua [in Ukrainian].

40. Analitychna dovidka. Stan rozvytku nauky i tekhniky, rezultaty naukovoi, naukovo-tekhnichnoi, innovatsiinoi diialnosti, transferu tekhnolohii za 2015 rik. Analytical Reference. The state of science and technology development, the results of scientific, scientific and technical, innovation, technology transfer for 2015], Retrieved from https://mon.gov.ua/storage/app/media/nauka/infor matsiyno-analitychni/2-3-ad-kmu-2015.pdf [in Ukrainian].

41. Naukova ta innovatsina dialnist v Ukraini (2016) [Scientific and innovation activity in Ukraine. Statstical Collection] ukrstat.gov.ua. Retrieved from http://www.ukrstatgov.ua/druk/publicat/kat_u/publnauka_u.htm [in Ukrainian].

42. High tech exports - country rankings. The Global Economy, Retrieved from http://www.theglobaleconomy.com/rankings/High_tech_exports/.

43. High-technology exports (current US\$). The World Bank. Retrieved from http://data. worldbank.org/indicator/TX.VAL.TECH.CD?end=2014\&name_desc=false\&start=1999. 
44. Ukaz Prezydenta Ukrainy Pro rishennia Rady natsionalnoi bezpeky i oborony Ukrainy vid 4 bereznia 2016 roku "Pro Kontseptsiiu rozvytku sektoru bezpeky i oborony Ukrainy" [Decree of the President of Ukraine On the decision of the National Security and Defense Council of Ukraine dated March 4, 2016, "On the Concept of the Development of the Security and Defense Sector of Ukraine"] (n.d.). zakon.rada.gov.ua. Retrieved from http://zakon5.rada.gov.ua/laws/show/92/2016 [in Ukrainian].

45. Byudzhet osvity to nauky 2013-2018 [The budget of education and science for 2013-2018]. CEDOS, docs.google.com, Retrieved

https://docs.google.com/spreadsheets/d/12dkloXQS3iXNurSGOo2ybBI_YhvOyN_GoObXlihjT8Q/edi\#\#gid=1706382291

[in Ukrainian].

46. Global Patent Applications Rose to 2.9 Million in 2015 on Strong Growth From China; Demand Also Increased for Other Intellectual Property Rights (2016). WIPO. Geneva, November 23, Retrieved from http://www.wipo.intpressroom/en/articles/2016/article_0017.html.

$\begin{array}{lllll}\text { 47. WPO IP Facts and Figures } 2016 & \text { (2016). WIPO. Geneva, Retrieved from }\end{array}$ http://www.wipo.intledocs/pubdocs/en/wipo_pub_943_2016.pdf.

48. Doklad UNESKO po nauke: na puty k 2030 hodu [UNESCO's Science Report Towards 2030]. UNESKO unesdoc.unesco.org. Retrieved from http://unesdoc.unesco.org/images/0023/002354/235407r.pdf [in Russian].

49. European patent applications. European Patent Office. Retrieved from http://www.epo.org/about-us/annual-reportsstatistics/annual-report2015/statistics/patent-applications.html\#tab6.

50. Your key to European statistics. Eurostat. Retrieved from $\mathrm{http}: / /$ ec.europa.eu/eurostat $\mathrm{tg} \mathrm{m} / \mathrm{table}$.do? tab=table \&init=1\&language =en\&p code=tsc00004\&plugin=1.

51. Singapore. Sea-eu-net partners in science. Retrieved from https://sea-eu.netfacts/sea/singapore\#_ftn4.

52. Pokaznyky nadkhodzhennia ta rozghliadu zaiavok i reiestratsii okhoronnykh dokumentiv za 2016 rik. (2016) [Indicators of receipt and consideration of applications and registration of security documents for 2016] UKRPATENT, uipv.org, Retrieved from http://www.uipv.org/ua/2016-year-expert [in Ukrainian].

53. Finansuvannia naukovykh doslidzhen $v$ Ukraini ta svit [Financing of scientific research in Ukraine and in the world]. Ekonomichnyi dyskusinyi klub - Economic Discussion Club. Retrieved from http://edclub.com.ua/analityka/finansuvannyanaukovyh-doslidzhen-v-ukrayini-ta-sviti [in Ukrainian].

54. Patent counts by origin and type calendar year 2015. U.S. (2015) Patent and trademark office. Retrieved from https://www.uspto.gov/web/offices/ac/ido/oeip/taff/st_co_15.htm.

55. Zakon Ukrainy "Pro okhoronu prav na vynakhody i korysni model" [Law of Ukraine "On Protection of Rights to Inventions and Utility Models"] (n.d.). zakon.rada.gov.ua. Retrieved from http://zakon5.rada.gov.ua/laws/show/3687-12/page [in Ukrainian]

56. Nakaz Fondu Derzhavnoho maina Ukrainy "Pro zatverdzhennia metodyky otsinky mainovykh prav intelektualno vlasnost" [Order of the State Property Fund of Ukraine "On Approval of the Methodology for Appraisal of Intellectual Property Rights"] (n.d.). zakon.rada.gov.ua. Retrieved from http://zakon5.rada.gov.ua/laws/show/z0726-08 [in Ukrainian].

57. Postanova Kabinetu ministriv Ukrainy Pro zatverdzhennia Natsionalnoho standartu № 4 "Otsinka mainovykh prav intelektualnoi vlasnost" [Resolution of the Cabinet of Ministers of Ukraine On Approval of National Standard No. 4 "Appraisal of Intellectual Property Rights"] (n.d.). zakon.rada.gov.ua. Retrieved from http://zakon5.rada.gov.ua/laws/show/1185-2007-\%D0\%BF [in Ukrainian].

58. Hargreaves, I. (2011) The recommendation to introduce text and data mining in the UK las already made in so called the Hargreaves review. Digital Opportunity A review of Intellectual Property and Growth. Available at Retrieved from http://webarchive.nationalarchives.gov.uk/20140603093549/http://www.ipo.gov.uklipreview-finalreportpdf.

59. Tsili Yevropeiskoi Stratehii intelektualnoho, stabilnoho i produktyvnoho zrostannia. ec.europa.eu. Retrieved from http://ec.europa.eu/europe2020/europe-2020-in-a-nutshell/targets/index_en.htm [in Ukrainian].

I.E. Новікова, канд. екон. наук, с.н.с., Київський національний університет імені Тараса Шевченка (м. Київ, Україна);

B.C. Мартинюк, д-р біол. наук, професор, проректор з наукової роботи, Київський національний університет імені Тараса Шевченка (м. Київ, Україна):

О.P. Бедюх, канд. фіз.-мат. наук, с.н.с., Київський національний університет імені Тараса Шевченка (м. Київ, Україна);

0.0. Харіна, канд. екон. наук, н.с., Київський національний університет імені Тараса Шевченка (м. Київ, Україна)

Академічний капіталізм: українські тенденції формування та європейська практика

У статті визначено тенденції формування академічного капіталізму в Україі, а саме розкрито основи становлення наукоємного бізнес-середовища в Україні та світі, зокрема в університетах, а також виокремлено закономірності комерціалізації результатів науково-дослідної діяльності у контексті посилення значимості знань. Здійснено порівняльний огляд найбільш поширених інституційних форм передачі технологій в Україні та за кордоном. Одержані результати дозволять сформувати принципи для формування нової методичної парадигми керування процесом трансфреру технологій з урахуванням особливостей розвит ку вітчизняної науки, економіки, підприємництва та ринку високих технологій.

Ключові слова: академічний капіталізм, інновації, наукоємний бізнес, комерціалізація, центр транссреру технологій, науково-технічна продукція, патенти, євроінтеграція. 
I.E. Новікова, В.С. Мартинюк, О.Р. Бедюх, О.О. Харіна. Академічний капіталізм: українські тенденції формування та європейська практика

И.Э. Новикова, канд. экон. наук, с.н.с., Киевский национальный университет имени Тараса Шевченко (г. Киев, Украина);

B.C. Мартынюк, д-р биол. наук, профессор, проректор по научной работе, Киевский национальный университет имени Тараса Шевченко (г. Киев, Украина);

A.P.Бедюх, канд. физ.-мат. наук, С.Н.с., Киевский национальный университет имени Тараса Шевченко (г. Киев, Украина);

E.О. Харина, канд. экон. наук, Н.С., Киевский национальный университет имени Тараса Шевченко (г. Киев, Украина)

Академический капитализм: украинские тенденции формирования и европейская практика

В статье определены тенденции формирования академического капитализма в Украине. В частности, раскрыто основы становления наукоемкого бизнес-среды в Украине и мире, в частности в университетах, а также выделень закономерности коммерциализации результатов научно-исследовательской деятельности в контексте усиления значимости знаний. Осуществлен сравнительный обзор наиболее распространенных институциональных форм передачи технологий в Украине и за рубежом. Полученные результаты позволят сформировать фундаментальную базу для формирования новой методической парадигмы управления процессом трансфера технологий с учетом особенностей развития отечественной науки, экономики, предпринимательства, рынка высоких технологий.

Ключевые слова: академический капитализм, инновации, наукоемкий бизнес, коммерциализация, центр трансфера технологий, научно-техническая продукция, патенты, евроинтеграция.

Отримано 12.06 .2017 p. 